\title{
Assessment on Consequences and Benefits of the Smart Farming Techniques in Batticaloa District, Sri Lanka
}

\author{
Narmilan, $\mathrm{A}^{\mathrm{a}^{*}}$, Niroash, $\mathrm{G}^{\mathrm{b}}$, Sumangala, $\mathrm{K}^{\mathrm{c}}$ \\ a*narmilan@seu.ac.lk \\ ${ }^{a, b, c}$ Department of Biosystems Technology, Faculty of Technology, South Eastern University of Sri Lanka
}

\begin{abstract}
ICT in agriculture (e-Agriculture) is an emerging field focused on improving agricultural production and rural development. The study was aimed to identify the consequences, promotion and benefits of farmer community towards the e-agriculture. Therefore, primary data were collected from the randomly selected 158 farmers by means of a welldesigned questionnaire survey during the period of February to April, 2019. The demographic characteristics of the farming community showed that only $5.1 \%$ of respondents were illiterate in this area. According to the study, $36.1 \%$ of respondents used telephone as ICT tool for agriculture. $0 \%$ of respondents used any ICT tools. Consequences index (CI) ranged from 114 to 586, where 114 indicated that the farmers strongly disagreed that there would be some consequences by not using ICT and 586 indicated that the farmers accepted that they would suffer in the future by not using ICT in their agricultural activities. Promotion measures index (PMI) ranged from 508 to 618, where 508 indicated the farmers' response on the provision of a computer, Internet access, and technician to each village was comparatively less whereas 618 indicated that the farmers accept the provision of incentives and finance may promote the use of ICT by a greater extent. Benefits of usage index (BUI) ranged from 86 to 140, where 86 indicated that the response of farmers on the option "cheaper" was less and 140 indicated that the farmers accepted the use of ICT in Agriculture helps them to acquire timely information related to their particular agricultural activities. Limiting factors index (LFI) ranged from 100 to 454 , where 100 indicated that a high number of farmers strongly disagreed on "no perceived economic benefit" by using ICT and 454 indicated that a high number of farmers accept that the lack of training is the main limiting factor of using ICT in their agricultural activities.
\end{abstract}

Published by IJRP.ORG. Selection and/or peer-review under responsibility of International Journal of Research Publications (IJRP.ORG)

Keywords: Digital Agricultur; Farmers; ICT; Awareness; Problems based index; Batticaloa;

\section{Introduction}

Agriculture is the key contributor to growth of economies in developing countries accounting for more than $45 \%$ of their Gross Domestic Product (GDP) (Rahman, 2009). ICT in agriculture is an emerging field focusing on the enhancement of productivity. The advancement in ICT can be utilized for providing accurate, timely, relevant information and services to the farmers to facilitate an environment for more remunerative agriculture. ICT adoption for agriculture today remains a continuously studied critical issue, at regional, national, and international levels. ICT illiteracy, availability of relevant and localize contents in their own languages, easy and affordable accessibility and other issues as awareness and willingness for adoption of new technologies are the common problems in adoption of ICT in rural areas. Farm management, communication flows, information access, and personal leisure time are improved by benefits of ICT (Forfas, 2004). The efficiency, productivity and sustainability of agriculture sector are increased drastically by the use 
of Information and communication technologies (ICT) through e-Agriculture. With the improvement in telecommunications access the usage of ICT within agriculture remains slow. Warschauer (2004) stated a shift in emphasis to the social context could improve technology usage. Corea (2002) further suggested that social systems encouraged a change in behavior towards technologies which in turn would motivate people to continually use ICT's.

Positive impact of high agricultural products on access to food supply in the domestic market contributes in agricultural sustainability by improving agricultural practice. Agriculture is the backbone of the Sri Lankan economy and it contributes to higher Gross National Production (GNP) of Sri Lanka. Food crop production in Sri Lanka has been facing several challenges for many years. In Sri Lanka, few agriculture sectors use ICT in their day to day activities or agricultural production. For an example some tea sector participants use ecommerce applications and a few poultry and livestock farmers use ration formulating software to prepare feeds (Jayathilake et al., 2010). Gelb and Bonati (1998) revealed that presence of the internet is very useful for present day agriculture. The complexity of farm, degree of external support, age, time, experiences, network, and availability of information, personality and approach to learning diminished a framer's computer use (Iddings and Apps, 1990). The most important limiting factors in developing countries in terms of infrastructure and cost of technology are no longer a threshold for ICT adoption in developed countries (Kurtenbach and Thompson, 2000). The study was conducted in Eravur Pattu, Batticaloa District in Sri Lanka. It was focused on identifying the consequences, promotion and benefits of farmer community towards the e-agriculture and assessing the views of farmer towards the e-agriculture and relationship between different socio-economic characteristics of respondents with the use of Information and Communication Technologies.

\section{Methodology}

This study was continued with the primary data collection from the farmers, who live in the Eravur Pattu, Batticaloa District in Sri Lanka by means of a questionnaire survey among randomly selected 158 farmers (The following formula was used to determine the samples size $(n) ; n=N * X /(X+N-1)$, where, $X=Z \alpha / 22$ $-{ }^{*} \mathrm{p}^{*}(1-\mathrm{p}) / \mathrm{MOE} 2$, and $\mathrm{Z} \alpha / 2$ is the critical value of the Normal distribution at $\alpha / 2$ (e.g. for a confidence level of $95 \%, \alpha$ is 0.05 and the critical value is 1.96 ), MOE is the margin of error, $\mathrm{p}$ is the sample proportion, and $\mathrm{N}$ is the population size (Daniel, 1999)) during the period of February to April 2019. The questionnaire had already been tested for its reliability and validity and verified by interviewing the 25 farmers in the region (who are not part of the sample studied). The data were collected in the respondents' questionnaire in their mother tongue and location. For collection of primary data, a well-structured interview schedule was developed and pretested in the field for 30 minutes and the priority was given to answer the question until the respondent feel free and relax. Then the secondary data were collected from Agrarian Service Center and Divisional Secretariat in Eravur Pattu, Chenkalady. Information on demographic characteristics of the farmers, awareness over the e-agricultural concept and usage of ICT tools for improving the agricultural productivity were included in the questionnaire form. In addition, questions were formulated to receive the right feedback from the respondents and the ideas regarding the e-Agriculture.

Different statements were selected under each category of the measurement. The categories of the measurement were "consequences for farmers not using ICT", "measures to promote the use of ICT by 
farmers", "benefits of using ICT in agriculture" and "factors limiting the use of ICT in agriculture" and the amount selected statements for each category was nine, seven, seven and eleven respectively. A five-point scale was developed to measure each category. The farmers were requested to respond as strongly disagree, disagree, neutral, agree and strongly agree for each statement. The weighted scores to their respective responses assigned were $0,1,2,3$ and 4 . So as to compare the statements under each category, a rank order was prepared in descending order. The developed Indexes for each category were Consequences Index (CI) as shown in Table 5, Promotion Measures Index (PMI) as shown in Table 6, Benefits of Usage Index (BUI) as shown in Table 7 and Limiting Factors Index (LFI) as shown in Table 8 respectively.

\subsection{Measurement of the Indexes}

The Index (Roy and Mondal, 2015; Rashid and Islam, 2016; Alam et al., 2018) of each category was calculated using the following formula:

Where,

$$
\text { Index }=4 x f v+3 x f h+2 x f m+1 x f l+0 x f n
$$

$\mathrm{fv} \quad=$ Number of respondents who responded strongly agree

fh $\quad=$ Number of respondents who responded agree

$\mathrm{fm} \quad=$ Number of respondents who responded neutrally

$\mathrm{fl} \quad=$ Number of respondents who responded disagree

fn $\quad=$ Number of respondents who responded strongly disagree

Finally, the raw data was gathered and spread in a Microsoft Excel spreadsheet and fed to the SPSS (Version 25) software to determine the demographic characteristics of the farmers and association between ICT applications of the farmers in the study area.

\section{Results and Discussion}

\subsection{Socioeconomic characteristics of farmers}

Table 1: Demographic characteristics of farming community

\begin{tabular}{|c|c|c|c|c|c|}
\hline Age of the respondent (years) & Number & Percentage & Education & Number & Percentage \\
\hline Below 25 & 2 & 1.3 & Primary & 24 & 15.2 \\
\hline $25-44$ & 64 & 40.5 & Intermediate & 106 & 67.1 \\
\hline $45-64$ & 84 & 53.2 & Advanced & 10 & 6.3 \\
\hline \multirow[t]{2}{*}{$65-84$} & 8 & 5.1 & Higher & 10 & 6.3 \\
\hline & & & None & 8 & 5.1 \\
\hline Ownership of the Land & & & $\begin{array}{c}\text { Land Extent for Paddy } \\
\text { (acres) }\end{array}$ & & \\
\hline Own & 80 & 50.6 & $0.6-1.0$ & 2 & 1.3 \\
\hline Lease & 22 & 13.9 & $1.1-2.0$ & 6 & 3.8 \\
\hline \multirow[t]{3}{*}{ Own and Lease } & 56 & 35.4 & $2.1-3.0$ & 6 & 3.8 \\
\hline & & & $3.1-4.0$ & 12 & 7.6 \\
\hline & & & Above 4.0 & 132 & 83.5 \\
\hline Farming Experience (Years) & & & $\begin{array}{l}\text { Monthly Income of } \\
\text { Household Head }\end{array}$ & & \\
\hline Below 25 & 111 & 70.3 & Below10,000 Rs & 23 & 14.6 \\
\hline $25-44$ & 45 & 28.5 & $10,001-20,000 \mathrm{Rs}$ & 49 & 31.0 \\
\hline \multirow{3}{*}{$45-64$} & 2 & 1.3 & $20,001-30,000 \mathrm{Rs}$ & 37 & 23.4 \\
\hline & & & $30,001-40,000 \mathrm{Rs}$ & 43 & 27.2 \\
\hline & & & Above $40,000 \mathrm{Rs}$ & 6 & 3.38 \\
\hline
\end{tabular}


The demographic characteristics of the farming community showed that $40.5 \%$ and $53.2 \%$ of respondents belonged to the 25-44 age group and the 45-64 age group respectively. Only $1.3 \%$ of respondents were under 25 and $5.1 \%$ were between $65-84$ age group. It was also revealed that in figure 2, the $5.1 \%$ of respondents were illiterate, $15.2 \%, 67.1 \%$ and $6.3 \%$ respectively had primary (grade 1-5), intermediate (grade 6-11) and advanced level (grade 12-13) education. Only 6.3\% had completed high school (degree level). The data also shows that the $50.6 \%$ of respondents were landowners who farmed their land. Similarly, renters accounted for $13.9 \%$, while homeowners and renters accounted for $35.4 \%$ (Figure 6). Property status revealed that $1.3 \%$, $3.8 \%, 3.8 \%$ and $7.6 \%$ of respondents had properties with an area 0.6 to 1.0 acres, $1.1-2.0$ acres $2.1-3.0$ acres and 3.1-4 acres respectively. Experience is very important in any field of life to gain benefits and quality. According to the results of the study, the maximum respondents had less than 25 years of experience in agriculture, $28.5 \%$ between 25 and 44 years and only $1.3 \%$ had between 45-64 years of experience in agriculture. According to the data, the $14.6 \%$ income of respondents (LKR) ranged less than 10,000 per month. Similarly, $31 \%$ of respondents have 10,001 to 20,000 people per month, $23.4 \%$ of respondents 20,001 to 30,000 per month, $27.2 \%$ of respondents 30,001 to 40,000 per month and $3.38 \%$ of respondents earned more than 40,000 people per month.

\subsection{ICT tools employed by the farmers}

Table 2: Kind of ICT tools employed by the farmers

\begin{tabular}{c|c}
\hline ICT tools & Percentage of responses \\
\hline Computer & $25.0 \%$ \\
Internet & $22.2 \%$ \\
Telephone & $36.1 \%$ \\
Email & $8.3 \%$ \\
All of above & $0 \%$ \\
None of above & $8.3 \%$ \\
\hline
\end{tabular}

Table 2 shows the usage of ICT tools by farmers. According to the data $36.1 \%$ of farmers used telephone. Computer and internet were used by $25 \%$ and $22.2 \%$ of farmers respectively. Although, email was used by least number of farmers. But compared to the farmers who used ICT tools, the farmers not using ICT tools were very less in number. There was 0\% percentage of farmers who used all ICT tools mentioned here and there were some farmers who were not using any ICT tools. Khan et al. (2010) stated that telephone and mobile phone could be as major source of agricultural information. Chhachhar et al (2014) reported that modern ICT tools such as mobile phones are used to transfer the knowledge and information about agriculture market technology to farmers effectively. And also, he added more in his study that this improves the farming output and makes easy access to market. Otter and Theuvsen (2014) stated not only the mobile phones but also Email had positive impact on farm production of small farmers.

\subsection{Usage of agricultural activities by ICT tools}

Table 3: Agricultural Activities with ICT tools

\begin{tabular}{cc}
\hline Agricultural activities & Percentage of responses \\
\hline Plough & $11.3 \%$ \\
Irrigation & $16.9 \%$ \\
Fertilizer & $16.9 \%$ \\
Insect pest & $19.7 \%$ \\
Harvesting & $19.7 \%$ \\
Post-harvest & $0.0 \%$ \\
Marketing & $15.5 \%$ \\
Cattle management & $0.0 \%$ \\
\hline
\end{tabular}


Table 3 shows the agricultural activities used by the farmers with the help of e-Agriculture in Eravur Pattu, Batticaloa district in Sri Lanka. According to this data; the farmers were not using postharvest techniques with the help of e- Agriculture. Insect pest management and harvesting techniques were used by $19.7 \%$ of farmers. This shows the highest percentage of farmers who were engaged with these techniques with the help of eAgriculture. Irrigation and fertilizer application were done with the help of e-agriculture by $16.9 \%$ of farmers. $15.5 \%$ of farmers used marketing techniques with the help of e-Agriculture. Least percentage $(11.3 \%)$ of farmers was using e-agriculture techniques in ploughing. Stienen et al (2007) stated that ICT can be used for pest and disease control, especially early warning systems, new varieties, new ways to optimize production and regulations for quality control. Meera et al (2004) discussed on her study that ICT could help accessing farm management information and management of pests and diseases.

\subsection{Modern agricultural practices used by farmers}

Table 4: Modern agricultural practices used by farmers

\begin{tabular}{cc}
\hline Modern agricultural practices & Percentage of responses \\
\hline Irrigation techniques & $13.2 \%$ \\
Modern animal rearing & $0.0 \%$ \\
Modern agricultural machines & $10.5 \%$ \\
Hydroponics & $0.0 \%$ \\
Agricultural automation system & $0.0 \%$ \\
Fertilizer application & $5.3 \%$ \\
Pest and diseases management & $23.7 \%$ \\
Harvesting practices & $47.4 \%$ \\
\hline
\end{tabular}

Table 4 shows modern agricultural practices used by farmers. $47.4 \%$ of farmers used modern harvesting practices. This shows that highest number of farmers were using modern harvesting practices compared to other modern practices. Modern techniques of pest and disease management were used by $23.7 \%$ of farmers. Irrigation techniques and modern agricultural machines were used by $13.2 \%$ and $10.5 \%$ of farmers respectively. Modern fertilization practices were used by least number of farmers (5.3\%). No farmers were using modern animal rearing, hydroponics and agricultural automation system. Singh and Singh (2012) also opined that hydroponics is the technique of growing plants in soil-less condition helps to face the challenges of climate change and also helps in production system management for efficient utilization of natural resources. According to this data, farmers could easily harvest with the help of modern techniques. This could save the time and energy. Fredrick (2013) stated that E- agriculture will empower farmers to adopt customized seeds, animals and farming techniques that are unique to their needs having.

\subsection{Rank order of the consequences for farmers not using ICT}

The variables which were used to measure the consequences for farmers not using ICT and their respective ranks are shown in Table 5. Based on the results of CI it was detected that "problems in the future" ranked first and followed by "loss of contact with timely (market) information", "loss of contact with information and innovations", "loss of competitiveness", "loss of production and management efficiency", "loss of income and/or subsidies", "loss of customers", "stoppage of production" and "none" respectively. CI ranged from 114 to 586, where 114 indicated that the farmers strongly disagreed that there will be some consequences by not using ICT and 586 indicated that the farmers accepted that they will suffer in the future by not using ICT in 
their agricultural activities. A comparative study showed that the decisions made by the farmers in Uttar Pradesh, India using ICT-based information were much better on different farming activities than non-users of ICT (Ali, 2011).

Table 5. The rank order of the consequences for farmers not using ICT

\begin{tabular}{|c|c|c|c|c|c|c|c|}
\hline Consequences & $\begin{array}{l}\text { Strongly } \\
\text { Agree (4) }\end{array}$ & $\begin{array}{l}\text { Agree } \\
\text { (3) }\end{array}$ & $\begin{array}{l}\text { Neutral } \\
(2)\end{array}$ & $\begin{array}{l}\text { Disagree } \\
\text { (1) }\end{array}$ & $\begin{array}{c}\text { Strongly } \\
\text { Disagree (0) }\end{array}$ & Index & Rank \\
\hline Problems in the future & 132 & 14 & 8 & 0 & 4 & 586 & 1 \\
\hline $\begin{array}{l}\text { Loss of contact with timely (market) } \\
\text { information }\end{array}$ & 124 & 14 & 8 & 6 & 6 & 560 & 2 \\
\hline $\begin{array}{l}\text { Loss of contact with information and } \\
\text { innovations }\end{array}$ & 94 & 20 & 38 & 0 & 6 & 512 & 3 \\
\hline Loss of competitiveness & 98 & 14 & 20 & 10 & 16 & 484 & 4 \\
\hline $\begin{array}{l}\text { Loss of production and management } \\
\text { efficiency }\end{array}$ & 88 & 18 & 30 & 4 & 18 & 470 & 5 \\
\hline Loss of income and/or subsidies & 88 & 8 & 32 & 6 & 24 & 446 & 6 \\
\hline Loss of customers & 62 & 8 & 48 & 0 & 40 & 368 & 7 \\
\hline Stoppage of production & 56 & 20 & 32 & 12 & 38 & 360 & 8 \\
\hline None & 16 & 8 & 12 & 2 & 120 & 114 & 9 \\
\hline
\end{tabular}

As the comparative study shows the respondents who were not using ICT in the farmers expressed that they might face problems in the long run when they have to compete with the ICT using farmers as shown in Table 1. The EFITA questionnaire study performed in Glasgow in 2007 shows that the respondents expressed "loss of competitiveness" as an immediate consequence (Gelb and Voet, 2009) whereas "loss of competitiveness" scored $4^{\text {th }}$ rank in the present study. In the EFITA questionnaire study, it was expressed that "problems in the future" as the least consequence (Gelb and Voet, 2009) whereas "problems in future" was the immediate consequence in the present study. The contrasting features between the study areas and targeted populations might be the reason for contrasting results.

3.6 Rank order of the measures to promote the use of ICT by farmers

Table 6. The rank order of the measures to promote the use of ICT by farmers

\begin{tabular}{|c|c|c|c|c|c|c|c|}
\hline $\begin{array}{l}\text { Measures to promote the use of ICT by } \\
\text { farmers }\end{array}$ & $\begin{array}{l}\text { Strongly } \\
\text { Agree (4) }\end{array}$ & $\begin{array}{l}\text { Agree } \\
\text { (3) }\end{array}$ & $\begin{array}{l}\text { Neutral } \\
(2)\end{array}$ & $\begin{array}{l}\text { Disagree } \\
\text { (1) }\end{array}$ & $\begin{array}{c}\text { Strongly } \\
\text { Disagree (0) }\end{array}$ & Index & Rank \\
\hline Providing incentives and finance & 144 & 14 & 0 & 0 & 0 & 618 & 1 \\
\hline Educating and training the farmers & 136 & 18 & 4 & 0 & 0 & 606 & 2 \\
\hline $\begin{array}{l}\text { Translate ICT services to local languages and/or } \\
\text { dialects }\end{array}$ & 130 & 12 & 14 & 0 & 2 & 584 & 4 \\
\hline Extension and ICT center & 126 & 20 & 8 & 4 & 0 & 584 & 4 \\
\hline $\begin{array}{l}\text { Providing a computer, Internet access and } \\
\text { technician to each village }\end{array}$ & 102 & 20 & 18 & 4 & 14 & 508 & 7 \\
\hline
\end{tabular}

The variables which were used to calculate the measures used to promote the use of ICT by farmers and their respective ranks are shown in Table 6. Based on the results of PMI it was perceived that "providing incentives and finance" ranked first and followed by "educating and training the farmers", "demonstrations of ICT systems", "translate ICT services to local languages and/or dialects", "extension and ICT center", "develop suitable software" and "providing a computer, Internet access, and technician to each village" respectively. PMI ranged from 508 to 618 , where 508 indicated the farmers' response on the provision of a computer, 
Internet access, and technician to each village was comparatively less whereas 618 indicated that the farmers accept the provision of incentives and finance may promote the use of ICT by a greater extent. There is a need to promote the widespread use of modern information technologies for communication between researchers, farmers, and extension workers in order to transfer technologies and information in a cheaper way (Zijp, 1994). Income acts as one of the potential obstacles for rural farmers therefore their economic level has to be improved. Further, farmers have to be trained for ICT knowledge (Lokeswari, 2016). The farmers were expecting incentives and financial aid to incorporate ICT in their farming activities as the results shown in Table 2. Provision of ICT services such as the Internet and SMS services at a low cost and providing incentives and financial aids may promote the usage of ICT in the study area.

\subsection{Rank order of the benefits of using ICT in Agriculture}

Table 7. The rank order of the benefits of using ICT in Agriculture

\begin{tabular}{|c|c|c|c|c|c|c|c|}
\hline Benefits of Using ICT in Agriculture & $\begin{array}{c}\text { Strongly } \\
\text { Agree (4) }\end{array}$ & $\begin{array}{c}\text { Agree } \\
\text { (3) }\end{array}$ & $\begin{array}{l}\text { Neutral } \\
\text { (2) }\end{array}$ & $\begin{array}{c}\text { Disagree } \\
\text { (1) }\end{array}$ & $\begin{array}{c}\text { Strongly } \\
\text { Disagree (0) }\end{array}$ & Index & Rank \\
\hline Faster & 30 & 4 & 2 & 0 & 2 & 136 & 2 \\
\hline Easy Access & 24 & 8 & 2 & 0 & 4 & 124 & 4 \\
\hline Dissemination & 26 & 2 & 6 & 2 & 2 & 124 & 4 \\
\hline Storage & 18 & 4 & 14 & 0 & 2 & 112 & 6 \\
\hline
\end{tabular}

The variables which were used to measure the benefits of using ICT in Agriculture and their respective ranks are shown in Table 7. Based on the results of BUI it was perceived that the option "timely" ranked first and followed by the benefits "faster", "accurate", "easy access", "dissemination", "storage" and "cheaper" respectively. BUI ranged from 86 to 140 , where 86 indicated that the response of farmers on the option "cheaper" was less and 140 indicated that the farmers accept the use of ICT in Agriculture helps them to acquire timely information related to their particular agricultural activities. Information and communication technology (ICT) can improve farmers' access to agricultural information (Chapota et al., 2014) and it helps the farmers to access timely weather forecasts and other valuable information (Stienen et al., 2007). Further, ICT-based initiatives have helped farmers in states of India such as Madhya Pradesh, Uttar Pradesh, and Tamil Nadu to reduce transaction costs while obtaining information and carry out transactions in the entry and exit markets (Adhiguru, 2012). The response of farmers in Table 3 showed that they believe in the timely delivery of information by ICT usage in farming activities.

\subsection{Rank order of the measures to promote the use of ICT by farmers}

The variables which were used to measure the factors limiting the use of ICT in agriculture and their respective ranks are shown in Table 8. Based on the results of LFI it was perceived that "lack of training" ranked first and followed by "tradition and/or traditional practices", "no ICT access and/or infrastructure", "lack of (personal) ICT support services", "cost of ICT and/or funds", "impediments. E.g. age, knowledge, English", "time limitations", "too hard to use", "lack of ICT skills and inability to use", "fear and/or distrust of technology" and "no perceived economic benefit" respectively. LFI ranged from 100 to 454, where 100 indicated that a high number of farmers strongly disagreed on "no perceived economic benefit" by using ICT 
and 454 indicated that a high number of farmers accept that the lack of training is the main limiting factor of using ICT in their agricultural activities.

Table 8. The rank order of the measures to promote the use of ICT by farmers

\begin{tabular}{|c|c|c|c|c|c|c|c|}
\hline Limiting Factors & $\begin{array}{l}\text { Strongly } \\
\text { Agree (4) }\end{array}$ & $\begin{array}{c}\text { Agree } \\
(3)\end{array}$ & $\begin{array}{c}\text { Neutral } \\
\text { (2) }\end{array}$ & $\begin{array}{c}\text { Disagree } \\
(1) \\
\end{array}$ & $\begin{array}{c}\text { Strongly } \\
\text { Disagree (0) }\end{array}$ & Index & Rank \\
\hline Lack of training & 104 & 8 & 6 & 2 & 0 & 454 & 1 \\
\hline Tradition and/or Traditional practices & 102 & 4 & 12 & 2 & 0 & 446 & 2 \\
\hline No ICT access and/or infrastructure & 96 & 10 & 12 & 2 & 0 & 440 & 3 \\
\hline Lack of (personal) ICT support services & 90 & 8 & 18 & 0 & 4 & 420 & 4 \\
\hline Cost of ICT and/or funds & 58 & 18 & 16 & 2 & 26 & 320 & 5 \\
\hline Impediments (age, knowledge, English) & 46 & 8 & 14 & 2 & 50 & 238 & 6 \\
\hline Time limitations & 44 & 6 & 14 & 4 & 52 & 226 & 7 \\
\hline Too hard to use & 38 & 10 & 10 & 6 & 56 & 208 & 8 \\
\hline Lack of ICT skills and inability to use & 32 & 8 & 4 & 6 & 70 & 166 & 9 \\
\hline Fear and/or distrust of technology & 16 & 14 & 28 & 2 & 60 & 164 & 10 \\
\hline No perceived economic benefit & 10 & 8 & 16 & 4 & 82 & 100 & 11 \\
\hline
\end{tabular}

The spread of ICT among farmers was hampered by a number of factors such as cost, availability, and knowledge (Wolf, 2001; Chukwunonso et al., 2012; Mwakaje, 2018). While comparing the studies done in India and Europe, a large percentage of responses highlights (21.4 to 27.6\%) on "no perceived economic or other benefits" in Europe whereas in India 7\% in 2001 to $4.9 \%$ in 2006 shows the perceived advantages of ICT (Patil et al., 2008) and "no perceived economic benefit" was scored the $11^{\text {th }}$ rank in the present study. Further, Patil et al. (2008) reported that high illiteracy (85.7\% of responses) in India remains a significant personal barrier $(61 \%$ and $48.8 \%$ ) for the use of ICT in contrast to Europe (only $5.4 \%$ ) and "lack of training" was an obvious limiting factor in the present study area. The contrasting results might be due to the differences in the mode of ICT usage and the availability of ICT training in different locations.

\section{Conclusion}

This paper illustrates the contribution of ICT tools in agriculture. Earlier days farmers who were in the developed country mostly used e-agriculture for the enhancement of productivity. Nowadays farmers in the all over world including developing countries try to use e- agriculture system. Based on the demographic characteristics of farming community only $5.1 \%$ of respondents were illiterate in this area. $36.1 \%$ of respondents used telephone as ICT tool for agriculture.0\% of respondents used any ICT tools. In this study, under the consequences index, "problems in the future" when farmers are not using ICT has been ranked first likewise no other consequences faced by farmers when not using ICT has been ranked last. In promotion measures index, the provision of incentives and finance among farmers has been ranked first as well as the provision of a computer, Internet access, and technician to each village has been ranked last. Timely information regarding agriculture with the help of ICT has been ranked first and one of the benefits of using ICT is cheaper has been ranked last under the benefits of usage index. In limiting factors index, lack of training is the main limiting factor of using ICT has been ranked first and no perceived economic benefit" by using ICT has been ranked last. Therefore, usage of ICT plays a major role in agriculture in order to enhance the productivity. 


\section{References}

Adhiguru, P. and Devi, S. V., 2012. ICT in Indian Agriculture: Learnings and way Journal of Extension Education. 3(8): 1-4.

ahead. International

Alam, M. Z., Islam, M. S., and Kabir, M. H., 2018. Problems faced by the bean farmer in selected areas of Pabna district in Bangladesh. Research in Agriculture Livestock and Fisheries, 5(1): 11-18.

Ali, J., 2011. Use of quality information for decision-making among livestock farmers: role of information and communication technology. Livestock Research for Rural Development. 23-43.

Chapota, R., Fatch, P. and Mthinda, C., 2014. The Role of Radio in Agricultural Extension and Advisory Services-Experiences and Lessons from Farm Radio Programming in Malawi-MEAS Case study. 8.

Chhachhar, A.R., Querestic, B., Khushk, G.M. and Ahmed, S., 2014. Impact of ICTs in agriculture development. Journal of basic applied science research. 4: 281-288.

Chukwunonso, F., Abubakar, M. and Nkiru, O., 2012. The adoption of information and communication technology (ICT) in agriculture in Adamawa State, Nigeria. African Journal of Agricultural Research and Development. 5(3): 79-85.

Corea.S,, 2000. "Cultivating technological innovation for development", Elect. Journal of Information Systems in Developing Countries (EJISDC). 2(2):1-15.

Fredrick A, kimutai K, kefah R. and dorothy R., 2013. ICT Solution Architecture for Agriculture. IST-Africa Conference Proceedings.

Forfas.., 2004. (Forfás is Ireland's policy advisory board for enterprise, trade, science, technology, and innovation) http://www.forfas.ie/media/forfas050601_annual_report

rt_2004_english.pdf, (accessed March 2012).

Gelb, E.M. and Bonati, G., 1998. Evaluating internet for extension in agriculture. The journal of agricultural education and extension. 5(3): 211-216.

Gelb, E. and Voet, H., 2009. ICT Adoption Trends in Agriculture: A summary of the EFITA ICT Adoption Questionnaires (1999-2009). Abrufbar unter: http://departments. agri. huji. ac. il/economics/voetgelb. pdf. Letzter Zugriff. 20.

Iddings, R.K. and Apps, J.W., 1990. 'What Influence Farmers' Computer Use Journal of Extension, XXVIII (Spring).19-20.

Jayathilake H.A.C. K., Jayaweera B.P. A and Waidyasekera. E.C. S., 2010. ICT Adoption and Its' Implications for Agriculture in Sri Lanka. Journal of Food and Agriculture .

DOI: $10.4038 /$ jfa. v1i2.1799.

Khan, G.A., Muhammad, S., Chaudhry, K.M. and Khan, M.A., 2010. Present status and future preferences of electronic media as agricultural information sources by the farmers. Pakistan journal of agriculture science. 47: 166-172. 
Kurtenbach, T. and Thompson, S., 2000. Information Technology Adoption: Implications for Agriculture.

Lokeswari, K., 2016. A study of the use of ICT among rural farmers. International Journal of Communication Research, 6(3), 232.

Meera, S. N., Jhamtani, A. and Rao, D., 2004. Information and communication technology in agricultural development: A comparative analysis of three projects from India. Agren. Network Paper 135: 1-14.

Mwakaje, A. G. (2018). Information and communication technology for rural farmer's market access in Tanzania.

Otter, V. and Theuvsen, L., 2014. ICT and farm productivity: Evidence from the Chilean Agricultural export sector. In GIL Jahrestagung. 113-116.

Patil, V. C., Gelb, E., Maru, A., Yadaraju, N. T., Moni, M., Misra, H. and Ninomiya, S., 2008. Adoption of Information and Communication Technology (ICT) for agriculture: An Indian case study. In IAALD AFITA WCCA 2008. World Conference on Agricultural Information and IT.

Rahman. M.A., 2009.Use of Information and Communication Technologies (ICTs) by Agricultural Extensionists in the Gezira State, Sudan. ed. Wad Medani: Faculty of Agricultural Sciences, University of Gezira.

Rashid, S. M. M., and Islam, M. R., 2016. Problems faced by farmers in application of e- Agriculture in Bangladesh. Journal of Agricultural Economics and Rural Development, 3(1):79-84.

Roy, S. and Mondal, S., 2015. Women's involvement in Organic (Vegetables) Farming System Activities (OFSA) in Samsung district of North-East Thailand. IOSR Journal of Humanities and Social Science, 20(7): 8-13.

Singh, S. and Singh, B. S., 2012. Hydroponics - A technique for cultivation of vegetables and medicinal plants. In. Proceedings of 4th Global conference on -Horticulture for Food, Nutrition and Livelihood Options\|, 28-31 May 2012, Bhubaneshwar, Odisha, India. p.220.

Stienen, J., Bruinsma, W. and Neuman, F., 2007. How ICT can make a difference in agricultural livelihoods, International Institute for Communication and Development (IICD), The Commonwealth Ministers Reference Book - 2007.

Warschauer, M., 2004. Technology and Social Inclusion: Rethinking the Digital Divide. the MIT Press, Cambridge.

Wolf, S., 2001. Determinants and impact of ICT use for African SMEs: Implications for rural South Africa. In Center for Development Research (ZEF Bonn). Trade and Industrial Policy Strategies (TIPS), Annual Forum at Misty Hills, Mulderdrift (10-12 Sept 2001).

Zijp, W., 1994. Improving the transfer and use of agricultural information: A guide to information technology. The World Bank. 